\title{
Two Perspectives on the Performative Social Body: Teenage Make-up Routines in Fanfik and the Jeżycjada cycle
}

Two Perspectives on the Performative Social Body: Teenage Make-up Routines in Fanfik and the Jeżycjada cycle. The article discusses make-up as an important element in a storyworld of YA fiction. It uses examples taken from novels by two Polish authors, the well-established and acclaimed Małgorzata Musierowicz, the author of the Jeżycjada cycle (1977-2015), and Natalia Osińska, who has recently debuted with a novel entitled Fanfik (2016). The article shows that Osińska’s novel can be seen as a transformative rendition of Musierowicz's works. It also focuses on the paratexts adding meaningful context in the case of both Musierowicz and Osińska, as well as comments on the public recognition of Musierowicz's fiction, the responses of Musierowicz's fandom to the alleged ideological message of her novels, and the political agenda of the publishing house that put Osińska's book on the market. The concepts of the performative social body, the cosmetic paradox, and glamour are employed to argue that Osińska's book is intended as a critique of the world-view presented in Jeżycjada's storyworld. Although a direct relationship between the two fictional worlds cannot be established, the article highlights some tangent points between them: in both cases, make-up serves the expression of the value system. In the Jeżycjada cycle, it is presented mostly as disguise and deception even though at the same time discreet make-up is meant to be part and parcel of womens' lives. By contrast, featuring queer teenagers, Osińska's debut novel highlights the transformative function of cosmetics as tools used to create the social body.

Keywords: queer representation, young adult fiction, Musierowicz, Osińska, cosmetics, make-up, paratexts

Address: Kazimierz Wielki University in Bydgoszcz, Institute of Modern Languages and Applied Linguistics, ul. Grabowa 2, 85-001 Bydgoszcz, Poland. E-mail: a.mochocka@ukw.edu.pl. 
Две точки зрения на перформативное социальное тело: подростковый макияж в романах Fanfik и Jeżycjada. В тексте рассматривается макияж как важный элемент мира беллетристики для юных читателей. В статье использованы примеры из романов двух польских авторов: известной Малгожаты Мусерович, автора цикла Јеżycjada, и Натальи Осинской, которая недавно дебютировала с романом Fanfik. Текст объясняет тот факт, что роман Осинской был провозглашен своего рода интерпретацией произведений Мусерович. В статье проанализированы паратексты, создающие значимый контекст, в произведениях Мусерович и Осинской. Автор исследования затрагивает вопрос об общественном признании литературы Мусерович. В статье прокомментированы ответы фэндома писательницы на предполагаемое идеологическое послание ее романов и рассмотрена политическая позиция издательства, которое выпустило книгу Осинской на рынок. В статье также идет речь о концепции перформативного социального тела, косметического парадокса и гламура. Книга Осинской считается критикой мировоззрения, представленного в мире Jeżycjady. Хотя прямая связь между двумя вымышленными мирами не может быть установлена, между ними, безусловно, есть некоторые точки пересечения. В обоих случаях макияж служит для выражения системы ценностей. В цикле Јеżyсjada макияж представлен в основном как маскировка и обман, но в то же время сдержанный макияж - неотъемлемая часть жизни женщин. С другой стороны, описывая квир подростков, Осинская подчеркивает в своем дебютном романе трансформационную функцию косметики как инструмента, используемого для создания социального тела.

Ключевые слова: квир представление, беллетристика для юных читателей, М. Мусерович, Н.Осинская, косметика, макияж, паратексты

The following article is concerned with the motif of make-up in young adult fiction written by two Polish writers, Małgorzata Musierowicz and Natalia Osińska. Musierowicz is an acclaimed author of several books, with firmly-established reputation as the genre's leading figure. ${ }^{1}$ Osińska has recently debuted with a novel entitled, not without a reason, Fanfik [Fanfic]. Both Osińska and Musierowicz use make-up as a narrative device. It is intriguing to find out how exactly the motif of make-up is utilised by two authors belonging to different generations, specifically as Osińska’s project seems to be concerned with the renegotiation of the value system present in Musierowicz's storyworlds and has gained recognition as a palimpsestuous rendition of the renowned author's works. The following analysis into similar storyworlds could serve a diametrically different aim.

A storyworld is "a dynamic model of evolving situations, and its representation in the recipient's mind is a simulation of the changes that are caused by the events of the plot". It is "a system of relationships between individual existents", that is "the characters of the story and the objects that have special significance for the plot". 4

${ }^{1}$ In 2008 she was granted the local equivalent of the Hans Christian Andersen Award by the Polish section of IBBY.

${ }^{2}$ M.-L. Ryan, Story/Worlds/Media. Tuning the Instruments of a Media-Conscious Narratology, [in:] Storyworlds Across Media. Toward a Media-Conscious Narratology, ed. M.-L. Ryan and J.-N. Thon, Lincoln and London 2014, p. 33.

${ }^{3}$ Ibid., p. 32.

${ }^{4}$ Ibid., p. 34.

Miscellanea Posttotalitariana Wratislaviensia 7, 2017

(C) for this edition by CNS 
Taken from transmedia narratology, those definitions accentuate the dynamics of the interplay among various elements of the fictional world, and the role of the reader in the process of world-building. "Storyworlds as an imaginative experience", 5 and the readers "conceive fictional storyworlds on the model of the real world, and it will import knowledge from the real world to fill out incomplete descriptions". ${ }^{6}$

Musierowicz's and Osińska's novels are concerned with the process of growing up understood both as adapting to a specific socio-cultural environment and as finding one's own identity. The use of cosmetics as elements of storyworlds helps, for both Musierowicz and Osińska, to delineate the boundaries of the characters' social bodies and signify the major ideological differences between the storyworlds. In Osińska's text, the social body is an ongoing and fluid project: it can be subversively modified, changed, and transformed, despite the fact that society prescribes a selection of norms the body should follow; there is no essentialist "norm". Musierowicz's texts in turn seem to stand for the essentialist position that perceives the body as a fixed, "natural" entity. The characters from Musierowicz's novels grow up and get adjusted to social standards that could be termed aetonormative, e.g. defined, narrated, and controlled by adults even though they concern children and remain beyond adult experience. ${ }^{7}$ The essential innate qualities of those characters do not change - they could only be revealed or highlighted. As it seems, cosmetics possess divergent functions in the storyworlds of the two authors: as I show later, Musierowicz's texts situate them in the "make-up as deception" and "make-up as vanity" rhetoric, at the same time presenting them as part and parcel of femininity. Osińska's novel discusses the question of queer identity and focuses on the nuances of the use of cosmetics, showing make-up as a ritualised transformative performance that can either empower or disempower the person who wears it, depending on broader and closer contexts.

I open my discussion with a brief presentation of the definition of the performative social body, as understood by Jennifer Craik, and relate it to the concept of glamour as well as the question of socially acceptable make-up. Then, I look at Małgorzata Musierowicz's fiction and the differences in the reception of the Jeżycjada and the so-called Neo-Jeżycjada books. Then I go on to discuss Natalia Osińska's novel palimpsestuous relationship to Musierowicz's novels. My analysis employs the theories of convergence/participatory culture, paratextuality, and the horizon of expectations. The political contexts that heavily influence Fanfik's reception are going to be introduced here as well. Finally, I focus on the function of make-up in Musierowicz's Szósta klepka [The Sixth Wit] and selected other texts. I also explore make-up routines that support the theme of 'body as performance' in Osińska.

\footnotetext{
${ }^{5}$ Ibid.

${ }^{6}$ Ibid., p. 35.

${ }^{7}$ M. Nikolajeva, "Theory, Post-Theory, and Aetonormative Theory," Neohelicon XXXVI (2009) 1, 13-24, pp. 16, 18.
} 


\section{Performative social body and cosmetics}

This section delineates a selection of terms related to the cultural reading of make-up routines. It is grounded in the general theories of performative social body, body decoration, and glamour, applicable to different cultures across history and as such useful in the analysis of both Musierowicz's and Osińska's texts.

Performative social body, as it is understood in the further discussion presented in this article, can be perceived as what is constructed out of the "attributes of self [...] constituted by the appearance achieved through body decoration". ${ }^{8}$ It is performative, which means that to be created it requires some effort and engagement ("an active process or technical means for constructing and presenting a bodily self"'). To use the tools offered by Richard Schechner's theory of performance and Erving Goffman's social interaction studies, it could be concluded that the body is an outcome of a certain process or a pattern that has become a ritualised behaviour ${ }^{10}$ and is thus meant to have some impact on the observers. ${ }^{11}$ Performative social body is achieved with the help of body decoration that could be executed "temporarily through paint, ornaments, or scents, or permanently through pierced ears, tattooing, scarification, or lip plugs, ${ }^{\prime 2}$ and occurs in every human culture. ${ }^{13}$ Specific practices of body decoration are, however, dependent on the "particular relations between body and habitus". ${ }^{14}$ As Jennifer Craik observes, "all techniques of body decoration concern the relationship between the self and the social body". ${ }^{15}$ As further comments,

In semiotic terms, body decoration is an act of writing. [...] The written face constitutes a speech about the person and sets the rules of social interaction. [...] The social body exists through its decoration. [...] The social body is composed of characteristics and qualities of personhood to be explicitly signified, depending on the occasion. Different social bodies draw on culturally specific techniques. [...]. Each produces the social body in culturally specific ways. ${ }^{16}$

Body decoration is regulated by codes that vary under different circumstances, such as the character of a social group ${ }^{17}$, because the aim of creating the social body is partially related to satisfying the need of fitting in with the norms of a specific community. This is followed by the so-called cosmetics paradox, consisting in "a tension between individual projection and group membership." ${ }^{18}$ In other words,

\footnotetext{
${ }^{8}$ J. Craik, The Face of Fashion, London 2005, p. 150.

${ }^{9}$ Ibid., p. 1.

${ }^{10}$ R. Schechner, Performance Theory, New York and London 1977, p. 99.

${ }^{11}$ E. Goffman, The Presentation of Self in Everyday Life, Edinburgh 1956, p. 13.

12 J. Craik, op. cit., p. 149.

13 Ibid.

14 Ibid., p. 149.

15 J. Craik, op. cit., p. 149.

16 Ibid.

17 Ibid., p. 151.

18 Ibid., p. 150.
} 
body decoration both enhances and erases the individual qualities of a person, making that person first and foremost one of the members of a group. ${ }^{19}$ As Craik has it, "we use the way we wear our bodies to present ourselves to our social environment, mapping out our codes of conduct through our fashion behaviour. Our habitus of clothing creates a 'face' which positively constructs an identity rather than disguising a 'natural' body or 'real' identity". ${ }^{20}$ Having observed that, I should note that at the same time Western culture perceives body decoration as "a superficial gloss" ${ }^{\text {", }}$, henceforth denigrating the exact practice that it imposes on its members.

In Western cultures body decoration is invariably situated in the framework of consumer culture, and usually related to make-up. As consumer products, cosmetics possess both material and cultural functions. Originally, make-up might have been used for some utilitarian reasons, for example protection from the elements, but its primary function is cultural and involves a network of assumptions and beliefs:

As a rhetoric, make-up promises transformations. Surface blemishes are hidden, youth is regained, skin becomes smooth, but, above all, the make-up should not be visible in its component parts, only its transformative impression. Make-up is a woman's secret projection of her desired self-image. In western cultures, it has become an integral step to realising femininity as an achieved set of characteristics (Craik 1989). The body is equipped with attributes through masking and manipulation. As a body technique, makeup constructs sexual attributes (hence the use of signifiers of sexual arousal such as red lips, dilated eyes and reddened cheeks), in addition to attributes of selfhood and status. Make-up inscribes the attributes of personality onto the social body. Beauty is the achievement of make-up as a positive declaration of the self. As with other body techniques, the application of make-up is ritualised and routinised. ${ }^{22}$

Make-up is ripe with conflicting meanings. As pointed out above, popular as it is, make-up is often situated as trivial. ${ }^{23}$ It "has long been associated with moral infirmity - with effeminacy in men and unchastity in women, because in using cosmetics we at one and the same time indicate our readiness for flirtation and dalliance, and attempt to improve on Nature's - or God's - work". ${ }^{24}$ Even during the periods when make-up is commonly used, visible make-up could be problematic and "confined to theatrical uses and to ladies of 'ill-repute"'. 25 According to Lisa Eldridge (a make-up artist who also researches the history of make-up), societies oppressive towards women usually prohibited visible make-up but enforced their beauty standards (related to youthfulness and health) nonetheless, thus making it necessary for a woman to apply "discreet" make-up. ${ }^{26}$ In contemporary society,
${ }^{19}$ Ibid.
${ }^{20}$ Ibid., p. 4.
${ }^{21}$ Ibid., p. 1.
22 Ibid., p. 154.
${ }^{23}$ Ibid., p. 149.
${ }^{24}$ E. Wilson, Adorned in Dreams, London and New York 2003, p. 107.
25 J. Craik, op. cit., p. 154.
${ }^{26}$ L. Eldridge, Facepaint, New York 2015, Kindle. 
[...] the use of cosmetics has become a banal convention. A kind of hyper-naturalism is the norm on the streets of every city, large and small: lots of blusher, lots of foundation colour, lots of lipstick in a 'subtle' shade, the same with eye make-up. Women seem to wear this cosmetic 'uniform' in much the same spirit as most men wear ties - in order to look 'dressed', in order not to stand out from the crowd. The standardized styles of make-up 'art' are there, one feels, to reassure the wearer that she has not strayed too far outside the norms of reasonable good looks, of ordinary prettiness, rather than to 'make a statement' or 'express her personality. ${ }^{27}$

The research conducted by Katarzyna Murawska on three generations of Polish women supports this claim: the general assumption shared by Murawska's subjects was that a woman should look presentable. Regardless of their age, most women she interviewed wanted to look good, with the caveat that they wanted neither to stand out, nor draw too much attention to their appearance. ${ }^{28}$ The older an interviewed woman was, the less eager to experiment with her looks she declared herself. ${ }^{29}$ The young ones (secondary school and university students) were more open for experimentations and unconventional looks, still saving them for special occasions, for example evenings out or parties. ${ }^{30}$

This kind of body policing is usually perpetuated in the media, solidified by peer pressure, and transferred between generations, yet sometimes escalates to the level of outright violence. Extreme forms of body policing can be found in totalitarian regimes that strive "to exert moral control over the society", 31 an example being Iran after the Islamic revolution. In the early years after the revolution, make-up was counted amongst " $<<$ moral crimes $>>$ or $<<$ immoral behavior $>>$ ", 32 and soon a morality police, the Basij, was founded. "Wearing makeup, colorful scarves, and tight clothing"33 is still officially prohibited in Iran, and " $<<$ immoral $>>$ behavior is often used to express discontent with the regime and symbolize individuals' resistance to state power". ${ }^{34}$ While the morality police "would insist on wiping their faces", ${ }^{35}$ young women experiment with make-up, partially for their own satisfaction with their looks or to impress other people, and partially to defy the theocratic regime. ${ }^{36}$

${ }^{27}$ E. Wilson, op. cit., p. 114.

${ }^{28}$ K. Murawska, "Makijaż i praktyki upiększające w życiu trzech pokoleń kobiet," [in:] Od obyczaju do mody. Przemiany życia codziennego, ed. J. Zalewska and M. Cobel-Tokarska, Warsaw 2014, pp. 375-376.

${ }^{29}$ K. Murawska, op. cit., p. 376.

${ }^{30}$ K. Murawska, op. cit., pp. 374, 377.

${ }^{31}$ S. Golkar, "Politics of Piety: The Basij and Moral Control of Iranian Society," Journal of the Middle East and Africa 2, 2011, p. 208.

32 Ibid., p. 208.

33 Ibid., p. 217.

${ }^{34}$ Ibid., p. 219.

${ }^{35}$ P. Mahdavi, "Who Will Catch Me if I Fall? Health and the Infrastructure of Risk For Urban Young Iraniansa," [in:] Contemporary Iran. Economy, Society, Politics, ed. by A. Gheissari, Oxford 2009, p. 189.

${ }^{36}$ Ibid.

Miscellanea Posttotalitariana Wratislaviensia 7, 2017

(C) for this edition by CNS 
While so-called "make-up-no-make-up" could still be the norm, there is a contradictory approach to body decoration that asks for self-expression and exuberance. Body decoration is more often than not analyzed in terms of the beauty myth ${ }^{37}$ that regulates and polices female behaviour under the disguise of prescribing the norms of preferable appearance. It is beyond the scope of this text to discuss the variety of stances on the disempowering function of make-up. Nonetheless, as Elizabeth Wilson says, "what the feminist critique misses is the importance of exaggeration and of the extreme in contemporary standards of beauty" ${ }^{38}$ The theories of performative glamour, as developed by Virginia Postrel, Carol Dyhouse, or Stephen Gundle, perceive it as non-verbal persuasion that utilises the if-only principle (if only one can be as glamorous as those he or she admires!). ${ }^{39}$ Glamour is difficult to define, yet it can be approached as "a shared language of allure consisting of materialism, beauty, and theatricality" ${ }^{\prime 0}$, connected to the modern practices of consumption. ${ }^{41}$ In Gundle's words,

It is an enticing and seductive vision that is designed to draw the eye of an audience. It consists of a retouched or perfected representation of someone or something whose purpose it is to dazzle and seduce whoever gazes on it. ${ }^{42}$

Glamour relies on excess and abundance ${ }^{43}$, it "strikes the imagination by bypassing the commonly accepted bourgeois sense of moderation and measure". ${ }^{44}$ It

can capture the imagination by association with a range of qualities, including several or all of the following: beauty, sexuality, theatricality, wealth, dynamism, notoriety, movement, and leisure. The more of these that are present, the more glamorous the result and the more successful the image is likely to be in arousing wonder and envy among those who see it. ${ }^{45}$

What is specifically important here is that the concept of glamour differs significantly from the concept of beauty. The latter is understood as some inherent, inborn feature; glamour is artificial and as such can be obtained with the help of external means (fashion, make-up, jewellery etc.). In a way, glamour is that to beauty what performative gender is to the "fantasy" of the "true gender" 46 — both are situated as fabrication. Needless to say, drag aesthetics draws heavily from glamour, as drag

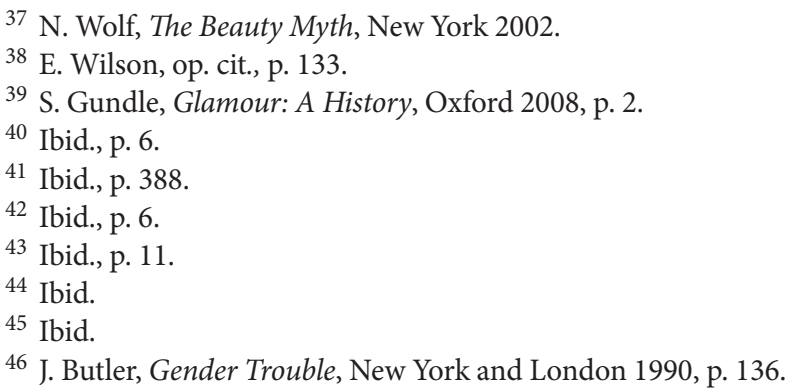


"parodies the notion of original or primary gender identity" 47 and playfully inverts gender identities.

To sum up, while modern societies tend to impose the standards of moderate and "natural" make-up-no-make-up styles, there is also the glamour approach to cosmetics that accepts artifice, excess, and exaggeration and contains subversive potential. Body decoration of either kind is used for the performative creation of the social body, determined by the specific habitus of the body in question. What lies at the core of the cosmetic paradox is that the social body is partially concerned with the projection of the individualistic self, and partially with the group pressure on not standing out. This makes make-up an extremely complicated phenomenon despite the popular assumption that the use of cosmetics is banal. Therefore, using make-up as a storyworld existent could result in a variety of meaningful outcomes, reaching far behind the enhancement of verisimilitude.

\section{Musierowicz and the concepts of Jeżycjada and Neo-Jeżycjada}

Born in 1945, Małgorzata Musierowicz has been publishing since the late 1970s. Her cycle of young adult novels depicts local intelligentsia (the Borejkos family, mostly) facing the changing social reality ${ }^{48}$ and invariably keeping their idealistic values. The early novels by Musierowicz were, and still are, considered foundational by numerous Polish readers. The latter ones, nicknamed the Neo-Jeżycjada by the fans (the most active gathering online to analyse Musierowicz's fiction), meet with criticism as, allegedly, repetitive and socially wrong. Dissatisfied fans claim that the Neo-Jeżycjada books lack both original content and good execution, and criticise the texts for perpetuating anti-feminist and anti-liberal values. This is, obviously, not a unison perception, and the bulk of scholarly criticism on Musierowicz still presents the author's writing in a highly favourable light.

One of the issues the fans criticise is the declarative inclusiveness of the Borejkos, who apparently lack the willingness to communicate with anyone who fails to share the family's world view. ${ }^{49}$ In Musierowicz's fiction this unwillingness is manifested, as those fans perceive it, by preventing "the characters endowed with the $<<$ wrong $>>$ attitudes or lifestyles to have their voice on equal grounds [with the $<<\operatorname{good}>>$ ones], and resorting to ridicule and caricature". ${ }^{50}$

As a matter of fact, some fans seem to have a love-hate relationship with Musierowicz. To quote a comment from the Kacza Zupa blog,

\footnotetext{
${ }^{47}$ Ibid., p. 137.

${ }^{48}$ K. Biedrzycki, “Dom, kobiety, kultura," Nowa Dekada Krakowska nr 1/2 (11/12) 2014, p. 24.

49 O. Dawidowicz-Chymkowska, "<<Wynaturzone >> Forum Fanów Małgorzaty Musierowicz jako interakcyjna maszyna interpretacyjna: studium przypadku,” Teksty Drugie 2012/6, p. 296.

${ }^{50}$ Ibid. (co wyraża się zwłaszcza poprzez niedopuszczanie do głosu na równych prawach bohaterów o "niewłaściwych" poglądach czy stylu życia, a uciekanie się zamiast tego do kpiny i karykatury)".
} 
Reading contemporary Musierowicz (for me, it has started with more or less Kalamburka) is like touching the gap left after a fresh tooth extraction with your tongue. You know you should not do this, as it is going to hurt, or there is even going to be some blood gushing, but you do this anyway. So I buy [the books] (mom help!), I read them and I grind [my teeth]. And then I nod with understanding, reading the selected threads on ESD. ${ }^{51}$

A term taken from Musierowicz's fiction, ESD means Eksperymentalny Sygnał Dobra [the Experimental Signal of Goodness], and it is currently the name of an Internet forum for active Jeżycjada fans, analysed by Dawidowicz-Chymkowska as "an interactive interpretative machine" 52 that facilitates "the co-existence in the discussion of at least two different types of discourses on literature, one of which is based on confessing the subjective reading experience and the other on the effort to negotiate a common interpretation within a scope of acceptable readings" ${ }^{53}$

To understand the transition from the old Jeżycjada to the Neo-Jeżycjada, and the liberally-oriented fans' dissatisfaction with the latter, it is necessary to explain the theory of islands [teoria wysp] as implemented in Musierowicz's works. Adapted from the philosopher and theatre theoretician Zbigniew Raszewski, who presented it in his correspondence with Musierowicz, the theory of islands could be seen as crucial for her fiction. It consists in the belief that in order to secure and save higher values - at risk in confrontation with the overwhelming communist regime - one had to hide inside a monad (a family or a closely knit community), keep away from the outside reality, and work primarily for the good of that "island". ${ }^{4}$

It is important to notice that in Musierowicz's texts the islands are governed and maintained by women: the author grants her female characters matriarchal power, as long as they stay within the limits of their households, while the outside world (politics, business, science) is reserved for men. ${ }^{55}$ Most of Musierowicz's female characters work outside of their homes, yet their professional careers are far less important than their parents, spouses, and children..$^{56}$ The positive female characters work but their professional lives "remain mythical", ${ }^{57}$ as in most cases the reader knows hardly

${ }^{51}$ DzikazRadzikiem, "Ratunku, jestem Romą! czyli o powieściach Małgorzaty Musierowicz słów kilka," [in:] Kacza Zupa, 27 August 2014, https://kaczazupa.wordpress.com/2014/08/26/ratunkujestem-roma-czyli-o-powiesciach-malgorzaty-musierowicz-slow-kilka (access: 30.06.2017): "Czytanie dzisiejszej Musierowicz (dla mnie tak mniej więcej od Kalamburki) to jak dotykanie językiem dziury po świeżo wyrwanym zębie. Wiesz, że nie powinnaś, że będzie bolało, a nawet poleje się krew, ale i tak to robisz. Więc kupuję (o mamo!), czytam i zgrzytam. A potem kiwam ze zrozumieniem na wybranych wątkach na forum ESD." [lost in translation is the gender of the subject who keeps on buying and reading Musierowicz, as the "you" in the fragment is followed with female inflections].

${ }^{52}$ Dawidowicz-Chymkowska, op. cit., p. 299.

${ }^{53}$ Ibid.

54 T. Piątek, "McDuszno," Krytyka Polityczna, 18 January 2013, http://krytykapolityczna.pl/ archiwum/felietony-archiwalne/tomasz-piatek/mcduszno/2013 (access: 30.06.2017).

${ }^{55}$ K. Biedrzycki, op. cit., pp. 25-26.

${ }^{56}$ B. Stankiewicz, "Model kobiecości w Jeżycjadzie," [in:] Świat literacki Małgorzaty Musierowicz, ed. A. Sulikowski and M. Niezgoda, Szczecin 2010, p. 117.

${ }^{57}$ Ibid., p. 118. 
anything about the details of their jobs. ${ }^{58}$ Musierowicz's texts are centred around the belief in "substantial femininity" 59 that finds best expression in motherhood ${ }^{60}$ and a symbiotic bond with a man. ${ }^{61}$ Motherhood and taking care of one's family are occupations that can be pursued inside the boundaries of the "island", as if the world outside did not need to exist.

The disillusionment expressed - vehemently at times - by some members of Musierowiczs fandom could be accounted for from the historical and socio-political perspective. Tomasz Piątek explains that

The theory of the islands is easy: we cannot change the rotten world, but we can create small islands or oases in which we can shut ourselves off, in which we live according to our rules: good is awarded, intelligence stimulated, and everything is permeated with warmth and light. The theory - even more the practice - is extremely exclusive (but of course, we will not let anyone marked with the Outer Rot inside, lest they defecate in the middle of our paradise island), but this is alleviated by the radiation principle. Our paradise island inhabitants try to radiate, walking down the streets and sending people smiles, or giving a nasty neighbour a piece of cake. First and foremost, they undertake defensive measures; they defend their small yet sacred spaces and symbols against the surrounding world. ${ }^{62}$

As Piątek suggests, the island theory was acceptable before 1989, in the Polish People's Republic, when social activism could meet with dire repercussions, but became questionable after the transition into a capitalist democracy ${ }^{63}$ According to Piątek, Musierowicz must have been severely disappointed with capitalism and unable to understand the changes it brought. ${ }^{64}$ The retreat to the secluded microutopia of the Borejko clan results in turn in the perpetuation of clichés and the petrification of the authorial vision: the characters depicted as negative could be perceived as one-dimensional and unconvincing cardboard figures, and the characters that are depicted as positive as idealised and unrelatable in the extreme ${ }^{65}$ :

The Borejkos got rid of the tv set, they turned their backs on politics and consumerism. The family children delight in poetry they write and recite. They do not play computer games, they do not

${ }^{58}$ Ibid.

${ }^{59}$ K. Dunin in B. Stankiewicz, op. cit., p. 114.

${ }^{60}$ B. Stankiewicz, op. cit., p. 115.

${ }^{61}$ Ibid., p. 123.

62 T. Piątek, op. cit.: “Teoria wysp jest bardzo prosta: parszywego świata nie zmienimy, ale możemy tworzyć małe wyspy czy też oazy, w których się zamykamy i w których żyjemy według naszych zasad: dobro jest nagradzane, inteligencja stymulowana, a wszystko przepaja ciepło i światło. Teoria ta - a tym bardziej praktyka - jest mocno ekskluzywistyczna (no bo przecież nie wpuścimy do nas kogoś, kto ma znamiona Zewnętrznej Parszywości, bo jeszcze nam zrobi kupę na środku naszej rajskiej wyspy), ale ten ekskluzywizm jest łagodzony przez zasadę promieniowania. Nasi rajscy wyspiarze starają się promieniować na zewnątrz, chodząc po mieście i posyłając ludziom uśmiechy, albo dając wrednej sąsiadce kawałek ciasta. Przede wszystkim jednak podejmują działania obronne, bronią swych małych, ale świętych przestrzeni i symboli przed otaczającym je światem."
${ }^{63}$ Ibid.
${ }^{64}$ Ibid.
${ }^{65}$ Ibid.

Miscellanea Posttotalitariana Wratislaviensia 7, 2017

(C) for this edition by CNS 
browse through Facebook, they do not watch porn. The main character [of McDusia] shakes with fear and shame, lest he sees the naked knees and arms of his beloved (and he immediately covers them with some blanket or a shawl). Only one boy uses the Internet $[\ldots]{ }^{66}$

Piątek admits that Musierowicz has always written escapist fiction; however, he postulates that even escapist fiction should maintain some verisimilitude, and, as he has it, "today this sweet picture reeks of disgusting deception, discernible from miles away" ${ }^{67}$ However, Musierowicz's position expressed in paratexts such as press interviews, and apparently sustained in her writing, is that an author is not a journalist, and neither should be, and the ugly reality does not need to be reflected in fiction - the author has got the right to create whatever pleases her. ${ }^{68}$ Leaving outside her storyworld Facebook, computer games, foreign travels, home decoration, digital gadgets, pop-culture, and numerous other activities pursued nowadays by the (aspiring) middle-class that has replaced the intelligentsia, Musierowicz may perhaps suggest that they belong to the "ugly reality", on a par with the communist shortages of goods and lack of civil rights. For people who build their identity in the post-communist free market liberalism, this is apparently unacceptable, as the vehement protests of the fans who criticise the Neo-Jeżycjada indicate.

\section{Osińska's Fanfik as the palimpsestuous rewriting of Musierowicz's narratives}

Fanfik [Fanfiction] is a young adult novel by Natalia Osińska, published in 2016 by Wydawnictwo Krytyki Politycznej. The plot is situated in contemporary Poland and pivots upon the dilemmas experienced by a transgender teenager. The main character has been assigned female at birth; despite his growing discomfort, he is raised up as an overfeminine girl by his single (widowed) father and his aunt, a beautician by profession. In the course of the plot he realises who he is and decides to come out. Another noteworthy character from Fanfik is a homosexual boy who has run away from his abusive family and tries to settle down in the new environment without disclosing his sexual orientation.

When it comes to the analysis of Fanfik, two important aspects should be taken into account. Firstly, there is the context of participatory/convergence culture, encouraging the production of derivative works. Such works rely strongly on the dialogi-

${ }^{66}$ Ibid.: "Borejkowie wyrzucili telewizor, odwrócili się od polityki i komercji. Dzieci z tej rodziny rozkoszują się poezją, którą piszą i deklamują. Nie grają w gry komputerowe, nie siedzą na fejsie, nie oglądają pornoli. Główny bohater drży ze strachu i wstydu, aby tylko nie zobaczyć nagich kolan i ramion swojej ukochanej (zaraz ją przykrywa jakimś kocem czy szalem). Internetem posługuje się tylko jeden chłopak".

67 Ibid.: "dzisiaj ten słodki obrazek jedzie obrzydliwym fałszem na kilometr".

${ }^{68}$ H. Maczunder, Humor i komizm sytuacyjny w wybranych powieściach Małgorzaty Musierowicz, Warszawa 2000, p. 9. 
cal references to already existing texts and use the techniques of remix and bricolage to achieve their artistic aims. ${ }^{69}$ Secondly, there are the theories of the horizon of expectations and paratextuality, drawing attention to the network of relationships in which a given text is situated. The meaning that recipients construct in the process of text reception is not only the outcome of their contact with the text per se, but also the result of their previous experiences with various phenomena related more or less closely to the text in question, which may, or may not, be verbal in form. In Fanfik, "the play with readers' expectations and habits takes place on numerous levels". ${ }^{70}$ Playing with double-coding, paratextuality, and intertexual allusions, Osińska opens her text to multiple interpretations.

Commenting on the horizon of expectations, Hans Robert Jauss notes that a text is never absolutely original and never exists in a vacuum. ${ }^{71}$ According to Gerard Genette, paratexts such as, for example, the title, the foreword, illustrations, marketing information, as well as the typographic elements and the physical form of the publication influence the reception ${ }^{72}$ :

[...] whether these productions are to be regarded as belonging to the text, in any case they surround it and extend it, precisely in order to present it, in the usual sense of this verb but also in the strongest sense: to make present, to ensure the text's presence in the world, its "reception" and consumption in the form (nowadays, at least) of a book. ${ }^{73}$

The tendency to take into account paratextual extensions seems to expand; there are numerous multimedia or multimodal texts, adaptations and transmediation of literary works, and the enormous growth of transmedia storytelling projects. Then again, the paradigm of convergence culture, mentioned above, dictates the relationships between creators and audiences: as Jenkins observes, far from being passive, audiences would actively go and look for satisfying experiences wherever they think they could find them. ${ }^{74}$ As a result, the creators decide to spread their content across multiple media platforms; they also implement incentives for the audiences to participate actively in reception. The theory of paratextuality aside, contemporary praxis as researched by Jenkins, among others, suggests that paratextual constituents such as the public image of the publishing house, interviews with the author, marketing announcements, the book title, the cover, video reviews, and Internet forum discussions play a valid function in the reception of the text, shaping the readers' horizon of expectations in specific ways, and as such should be taken into consideration and analysed along with the text.

${ }^{69}$ H. Jenkins, passim.

${ }^{70}$ A. Kobus, op. cit.: "gra na oczekiwaniach i przyzwyczajeniach czytelników odbywa się w niej na wielu poziomach".

${ }^{71}$ H. R. Jauss, 1999, Historia literatury jako prowokacja, Warszawa 1999, p. 145.

72 G. Genette, "Palimpsesty. Literatura drugiego stopnia," [in:] Współczesna teoria badań literackich za granica, ed. H. Markiewicz, Kraków 1992, p. 320.

73 G. Genette, Paratexts: Thresholds of Interpretation. Lincoln and London 2001.

${ }^{74}$ H. Jenkins, op. cit., pp. 2-3. 
In the case of Fanfik, the information concerning the publishing house is a significant paratext, and as such is going to be briefly analysed here. It suggests the ideological position of the text, the publishing house being, by design, far from 'politically neutral' in its mission. To quote the organisation's site, "Krytyka Polityczna (Political Critique) is the largest Central and Eastern European liberal network of institutions and activists" 75 , and its goal is to continue "the Central and Eastern European traditions of an engaged intelligentsia representing an ethos of public activity and creating a $<<$ social glue $>>$ through the use of social movements" ${ }^{36}$ To quote the organisation's self-presentation, again,

The Publishing House of Krytyka Polityczna was established in September 2007 [...] We were among the first in Poland to introduce new political and social theories [...], new historical perspectives [...], critical analyses of various social phenomena [...] or art and music [...]. In 2015 we published the worldwide bestseller in economics, Capital in the 21st Century by Thomas Piketty, heavily commented on in the Polish electronic media and press. We also re-edit classical works of literature and political writings, including works by Polish dissidents [...]. Moreover, we address to the most recent phenomena in politics and society by releasing books covering the Economic Crisis in the USA and Europe, Occupy! and Indignados movements or the (cultural) phenomenon of Polish mourning after the 2010 Smolensk plane crash and many others. We also publish important works on Jewish and Polish wartime memory $[\ldots]$ and on Poland's post-war cultural and social modernisation $[\ldots]{ }^{77}$

Among the authors published by the house there are Zygmunt Bauman, Gayatri Spivak, Terry Eagleton, Bruno Latour, Slavoj Žižek, Judith Butler, and Timothy Snyder. ${ }^{78}$ Given the self-publicised political activism of Krytyka Polityczna, as well as the projects they have executed, and taking into account the power play on the contemporary political scene in Poland, the organisation and its publications are by default situated on its left-wing. This alone can influence the reading of Osińska's novel. What is more, in the case of Fanfik, the publishing house ventured to release a novel focused on LGBT+ problems. Consequently, the positive reviews of the book are more often than not classified as "leftist delight" in the issues discussed in Fanfik, rather than fully justified appraisals ${ }^{79}$, an example of which could be the following quotation from an Internet forum:

BTW I have noticed on fb that Krytyka Polityczna advertises "Fanfik" almost ostentatiously. I say that in spite of the fact that I value Krytyka Polityczna as a medium. But it justifies my thesis that the young Polish left glorify this book just because they can't find anything better in Polish young adult fiction. ${ }^{80}$

75 “About Us," KrytykaPolityczna.pl, http://krytykapolityczna.pl/o-nas/eng (access: 20.06.2017).

76 Ibid.

77 Ibid.

78 Ibid.

${ }^{79}$ DzikazRadzikiem, op. cit.

80 "BTW zauważam na fb, że Krytyka Polityczna reklamuje "Fanfik" wręcz nachalnie. Piszę to całkiem niezależnie od tego, że cenię Krytykę Polityczną jako medium. Ale potwierdza się moja teoria, że młoda polska lewica zachwyca się tą książką z braku czegokolwiek lepszego w polskiej literaturze 
A similar opinion was expressed by one of Krytyka Polityczna’s own authors, Kinga Dunin, who states that "Fanfik is a politically correct fairy tale of a kind" ${ }^{81}$ It is difficult to deny that for numerous reviewers the novel tends to be recognised as a political statement and, to a great extent, the reason why it happens is its paratextual relation to Krytyka Polityczna.

Fanfik means "fanfiction", or "fic", in Polish. As a book title, it can be read as meaningful; it definitely shapes the reader's horizon of expectations. Does it indicate a novel about fan culture and fanfiction? The answer is, partially so. The main character writes fanfiction and gains a considerable readership online; when he gets in trouble, attacked by a cyberbully, his followers come to the rescue. Although this subplot is an important one, the details of his stories or the depiction of his creative process are not provided. One could argue, as it has been done by some reviewers (to be quoted later), that the entire life of the main character - his journey from body dysmorphia, through coming out, and towards acceptance - is structured and executed like a fanfic. But the question remains: what does this fanfic refer to?

As Gerald Prince comments on "the palimpsestuous nature of texts" 82 in the light of Genette's theory,

Any text is a hypertext, grafting itself onto a hypotext, an earlier text it imitates or transforms; any writing is rewriting, and literature is always in the second degree. Now though all literary texts are hypertextual, some are more hypertextual than others, more massively and explicitly palimpsestuous than others. ${ }^{83}$

Given a selection of tangent points, it could be suggested that there is a palimpsestuous relationship between Osińska’s Fanfik and Musierowicz’s Jeżycjada cycle. Obviously, there are numerous intertextual references in Osińska's text other than those related to Musierowicz's works. For example, the main character's name is initially "Tosia"; he changes it later to the male version, "Tosiek". This brings forth a classic Polish novel by Hanna Ożogowska, Dziewczyna i chłopak, czyli heca na 14 fajerek [The Girl and the Boy and the Fine State of Affairs] from 1961, which plays upon the theme of cross-dressing and features siblings called Tosia and Tosiek. ${ }^{84}$ Yet it should be noted that, rich in observations about the gender roles as it is, Ożogowska's text is not concerned with transsexuality or queer identity. Ożogowska's Tosia changes places with her elder brother, Tosiek, and spends her summer vacations dressed up as a boy, while he pretends to be his sister and dresses up as a girl. The situation is forced

młodzieżowej." by anuszka_ha3.agh.edu.pl, http://forum.gazeta.pl/forum/w,25788,162814260,162814 260,Natalia_Osinska_Fanfik_ktos_czytal_.html (access: 30.06.2017).

${ }^{81}$ K. Dunin, “Osobiście uważam, że...,” [in:] Krytyka Polityczna, 30 December 2016, http://krytykapolityczna.pl/kultura/czytaj-dalej/kinga-dunin-czyta/osobiscie-uwazam-ze (access: 30.06.2017): Fanfik to taka politycznie poprawna bajka".

82 G. Prince, "Foreword," [in:] Palimsests. Literature in the Second Degree, G. Genette, Lincoln and London 1997, p. ix.

${ }^{83}$ Ibid.

${ }^{84}$ H. Ożogowska, Dziewczyna i chłopak, czyli heca na 14 fajerek, Warszawa 1974. 
on the characters by a series of mishaps (Tosia tries to cover up for her brother, who misses an appointment, and when it is too late to back off, she decides to play his part), and has absolutely nothing to do with transgender identity the way Osińska’s novel discusses it. In Ożogowska's novel both children learn a lot about gender roles and the limitations the society imposes on both men and women but their temporal change of gender expression is not related to their internal gender identity and satisfaction with the gender ascribed to them at birth. Summing up, while definitely an important reference and a clever intertextual allusion, Ożogowskảs Dziewczyna $i$ chłopak could not be called the primary hypotext of Osińska's novel.

An indicator of a much closer relationship between two texts is the soft touch book cover designed by Anna Pluta for Osińska's text. The art on the cover presents the face of a young blue-eyed blonde-haired person in a hoodie. Given the contexts, this specific style of representation - a close-up of the main character's face - is highly suggestive of the covers of Musierowicz's young adult books (designed by the author herself), a fact recognised, by numerous readers, as the reviews (some are going to be referenced later) suggest.

Print technology enables a special technique to be applied here: when seen at a proper angle, the cover reveals a pattern of pill-shaped objects, glittering decoratively. The face is hidden behind a grid of gloss print pills, a fact to be noticed only if one knows how to look. Not only reminiscent of Musierowicz, the cover engages the reader in the act of revealing the hidden aspect of the text and serves as a metaphor of the hidden truth about the characters' lives. ${ }^{85}$ It is also aesthetically pleasing, as pointed at in numerous YouTube reviews, for example by Nessa ${ }^{86}$ : the reviewer keeps on playing with the book, moving her hand back and forth. Playing with the gloss print cover is reminiscent of playing with a novelty toy, for the sheer pleasure of experiencing the visual effect.

Fanfik's book cover situates the novel in the perspective of Musierowicz's fiction and its reception. In Poland, the association seems to be unavoidable. As a comment following a video review says: "At the beginning I was sceptical about the book, because a Polish author and the cover reminded me a lot of some other Polish author, unfortunately I don't remember her name" 87 (another user answers that the cover

85 The pills are another important existant here. Tosia/Tosiek takes medication that has a detrimental effect on her/his mental health. Osiańska has been criticised for her depiction of medicalised mental treatment, though, as she presents it as something negative and destructive. In the specific context of the novel, it really is so as the main character is forced into the treatment to keep Tosia/Tosiek from thinking about his gender identity.

${ }^{86}$ Nessa, "Najbardziej zaskakująca młodzieżówka," YouTube 9 December 2016, https://www. youtube.com/watch?v=2iIbWIbM1xA (access: 30.06.2017).

87 "Na początku nie byłam przekonana do tej książki, bo polska autorka i okładka bardzo mi się skojarzyła $\mathrm{z}$ taką inna polska autorką, niestety nie pamiętam jej nazwiska." stating1223, comment to lilacwix, "Fanfik - Natalia Osińska," [in:] YouTube, 11 January 2017, https://www.youtube.com/ watch?v=wfTCqzn0gUE\&lc=z120jv5jxobqcjneo22ng3wbzyuij3qyi04 (access: 30.06.2017). 
is reminiscent of Jeżycjada). Some participants of the ESD forum find the similarity denigrating or depriving Fanfik of originality:

What I have read is nice, but too strained and repetitive for a full-fledged novel. It lacks breath, and the creative freedom, and when it comes to language, there is a whiff of the latter-stage Musierowicz. Nonetheless, the cover adds to this association strongly. ${ }^{88}$

Thus, the paratexts (the front cover, the title) suggest a possible interpretation of the novel's status. The initial intuition is solidified by further similarities between Jeżycjada and Fanfik. As one of the reviewers has observed in relation to Osińska's Fanfik "it all resembles Szósta klepka by Musierowicz very much, when it comes to style and characters". ${ }^{9}$

Osińska's text takes place in the city of Poznań, which is also the location of Musierowicz's novels (a coincidence recognised by some of the reviewers). Location is a crucial existent in Musierowicz's Jeżycjada cycle ${ }^{90}$, a family saga set in the Jeżyce district of Poznań. In Jeżycjada, considerable attention is given to the verisimilitude of the representation of the city space, with the names, locations, and characteristics of streets, cafés, schools, and other facilities provided exactly as they functioned at the time a given novel was written. The Jeżycjada cycle succeeds in recovering the genius loci of both the district and Poznan in general. Musierowicz's fans are known to organise tours of Poznań, tracing the locations mentioned in the texts, most importantly the tenement house at Roosevelt Street 5, where the fictional family of the Borejkos lives. ${ }^{91}$ A guidebook, Poznań Borejków [the Borejko’s Poznań], discusses various excerpts from Jeżycjada against the information related to the city's architecture and history. ${ }^{92}$ Even though the genius loci is not as prominent in Fanfik as it is in Jeżycjada, still, situating the plot in Poznań brings it closer to Musierowicz's fiction.

Submerged in participatory culture and accustomed to palimpsestuous works, contemporary readers are willing to find relationships between Osińska’s debut novel and Musierowicz's fiction. As one reviewer has pointed out, "the novel [Fanfik] is exactly what the title states - fan fiction, fan creation, the transformative work

88 " $<<$ Gniocik $>>$ byłby dosłowny i nazbyt, moim zdaniem, wartościujący. A to, co przeczytałam jest fajne, tylko jak na pełnowartościową powieść trochę wysilone, naśladowcze. Brak tam oddechu, kreacyjnej swobody, a językowo naprawdę zalatuje późną Musierowicz. Zresztą okładka silnie dopowiada to skojarzenie." potworia, comment to Natalia Osińska - Fanfik - ktoś czytał?, 21 November 2016, http://forum.gazeta.pl/forum/w,25788,162814260,162814260,Natalia_Osinska_ Fanfik_ktos_czytal_.html (access: 30.06.2017).

${ }^{89}$ O. Marudzińska, "Manic pixie dream human - Fanfik Natalii Osińskiej," [in:] Meanwhile On Vulcan Blog, 5 December 2016, http://meanwhile-on-vulcan.blogspot.com/2016/12/manic-pixie-dreamhuman-fanfik-natalii.html?m=1 (access: 30.06.2017): “całość bardzo przypomina "Szóstą klepkę" Musierowicz w stylu i bohaterach.

${ }^{90}$ In Polish, Jeżycjada rhymes with Iliada, meaning The Illiad.

${ }^{91}$ D. Szczerba, "Wstęp," [in:] Poznań Borejków. Spacer z bohaterami powieści Małgorzaty Musierowicz, ed. K. Czachowska and D. Szczerba Poznań 2004, p. 10.

${ }^{92}$ Ibid. 
of love"93 — and appeals to the readership equipped with a specific interpretative baggage. ${ }^{94}$ To quote Alicja Szymańska:

To publish in the mainstream a novel that proudly announces to be a fanfic is obviously a provocation — and one that asks for an answer. Fanfic — for what? Well, just look at the cover. A lot has been written about the fact that Natalia Osińska's novel is a variation on the theme and at the same time a manifest of objection against Małgorzata Musierowicz's works. In the place of an extended intelligentsia clan we find here an average, slightly dysfunctional family struggling to make ends meet. The father tries so hard to support the family that he ends up with a broken spine, strained as he redecorates the flats that don't belong to him. ${ }^{95}$

The cultural background of the intended readership is also different here. ${ }^{96}$ "No one stumbles upon the editions of Leśmian [a classic Polish poet] or reads Seneca to understand their mothers. Tosiek [the main character] loves Wicked, dreams of going to London, watches bootlegs on YouTube, and makes allusions to Pratchett". ${ }^{\prime 7}$ As mentioned before, despite the expectations that might have been created by the title, the novel is not concerned with fandoms or fan fiction per se. ${ }^{98}$ At the same time, taking fan culture for granted and avoiding cumbersome info-dumps explaining, for example, what "mpreg" means, legitimises the storyworld from the perspective of a fandom member. ${ }^{99}$

The main point of the novel, however, seems to be the transformation of heteronormative positions of young adult fiction, including Musierowicz's canonical works. ${ }^{100}$ According to Eliza Szybowicz, sex is the primary drive fuelling the actions of Jeżycjada’s characters. ${ }^{101}$ Contrary to Piątek, she perceives Musierowicz's characters (including the pre-adolescent ones) as over-sexualised but points to the subli-

93 A. Kobus, "Najbardziej potrzebna książka 2016 roku,” [in:] Szuflada Net, 22 January 2017, http://szuflada.net/najbardziej-potrzebna-ksiazka-2016-roku-queerowe-dzieci-i-fanfik-recenzjaniewolna-od-spoilerow (access: 30.06.2017): "powieść jest dokładnie tym, co głosi tytuł — fanfiction, twórczością fanowską, tranformative work of love”.

${ }^{94}$ A. Szymańska, op. cit.

95 Ibid.: "Publikacja w oficjalnym obiegu powieści dumnie obwieszczającej, że jest fanfikiem, to oczywiście prowokacja - i to domagająca się odpowiedzi. Fanfikiem - do czego? No, wystarczy spojrzeć na okładkę. Sporo już napisano o tym, że powieść Natalii Osińskiej to w a r i a cj a n a te m at i jednocześnie programowy sprzeciw wobec twórczości Małgorzaty Musierow i c z. Zamiast wielopokoleniowej inteligenckiej familii mamy w niej przeciętną, nieco dysfunkcyjną rodzinę, która ledwo wiąże koniec z końcem. Ojciec tak bardzo stara się być podporą rodziny, że aż siada mu kręgosłup, nadwerężony podczas remontów cudzych mieszkań.”

96 Ibid.

97 Ibid.: “<<Fanfik >> ma też inny niż „Jeżycjada” krąg odniesień kulturowych. Nikt tu nie potyka się o tomiki Leśmiana i nie czyta Seneki, by lepiej zrozumieć własną matkę. Tosiek kocha "Wicked”, marzy o wyjeździe do Londynu, ogląda bootlegi na YouTubie i robi Pratchettowskie aluzje.”

98 Ibid.

99 A. Kobus, op. cit.

100 Ibid.

101 E. Szybowicz, "Była fanka czyta Musierowicz," [in:] Krytyka Polityczna, 11 February 2013, http://krytykapolityczna.pl/kultura/czytaj-dalej/byla-fanka-czyta-musierowicz (access: 30.06.2017). 
mation of sexuality in Musierowicz's cycle: according to Szybowicz, sex permeates the stories, present under the disguise of euphemisms such as "misty eyes, vertigo, soft knees, electricity, and magnetism". ${ }^{102}$ It is "monogamous, heterosexual, sanctioned by the [Catholic] sacrament of marriage, and sanctified by procreation" ${ }^{103}$, and coming from "the ostensibly adult narrative voice". ${ }^{104}$ Osińska’s transgression could be then categorised as "fix it" fanfiction, trying to correct what is considered to be wrong ${ }^{105}$, starting with heteronormativity.

Osińska presents, matter-of-factly, a queer teenager who is discovering and re-establishing his identity and yet fails to be a victim. The main character's agency stays in sharp opposition to the predominant trope of "bury your gays", which calls for the victimisation and annihilation of queer characters. ${ }^{106}$ As a result, the story ends with a (relatively) carefree and happy ending, a fact criticised by many, but endowed with its internal logic. ${ }^{107}$ While still within the limits of verisimilitude, the story gives readers hope and normalises the characters and their relationships. ${ }^{108}$ At the same time, the author specifically wanted to keep her text safe for children in view of their parents' criteria ${ }^{109}$, that is, she consciously avoided any explicit sexual content. As she mentioned, while writing Fanfik she was thinking about the parents of her intended readers in terms of the 'censors' or gatekeepers, and now she is satisfied that there are parents who do find it appropriate to recommend the book to their 11-year-olds. ${ }^{110}$

The apparent lack of sex- or physiology-related issues can be also read as suggestive of the fact that the young characters are at an earlier stage of transition/development, at which sex in itself is not yet an issue. ${ }^{111}$ Fanfik is, all in all, a teenage love story. ${ }^{112}$ It could also be observed that mainstream narratives about queer people are more often than not centred around sexuality and bodily functions: what seems to interest and fascinate (or repulse) the heteronormative majority is the sexual act rather than love and devotion between queer partners. In a way, by neglecting the physiological aspects of transition and avoiding writing about sex explicitly,

102 Ibid.

103 Ibid.: "Monogamiczny, heteroseksualny, sakramentalny, uświęcony prokreacją popęd płciowy".

104 M. Nikolajeva, "Theory, Post-Theory, and Aetonormative Theory," Neohelicon XXXVI (2009) 1, 13-24, p. 13.

105 A. Kobus, op. cit.

106 A. Szymańska, op. cit.; A. Kobus, op. cit.; noida, "Musierowicz w wersji LGBTQ, czyli Fanfik Natalii Osińskiej," [in:] Kacza Zupa Blog, 11 January 2017, https://kaczazupa.wordpress. com/2017/01/11/musierowicz-w-wersji-lgbtq-czyli-fanfik-natalii-osinskiej (access: 30.06.2017).

107 noida, op. cit.; A. Szymańska, op. cit.

108 noida, op. cit.

109 A. Kobus, "Przenieść fanfiction do mainstreamu — wolny od spoilerów wywiad z Natalią Osińską, [in:] Szuflada Net, 29 January 2017, http://szuflada.net/przeniesc-fanfiction-do-mainstreamu-wolnyod-spoilerow-wywiad-z-natalia-osinska (access: 30.06 .2017 ).

110 Ibid.

111 A. Szymańska, op. cit.

112 A. Kobus, op. cit. 
in her debut Osińska distanced herself from this discourse. The queer teenagers from Fanfik are first and foremost teenagers, entitled to romantic, not-yet-sexual, entanglements.

\section{Cosmetics and the (teenage) social body in Musierowicz}

In both storyworlds, the continuous one created in the Jeżycjada by Musierowicz and the one from Fanfik, cosmetics play an important, albeit inconspicuous, function. This could possibly be related to the presentation - pivotal for both Jeżycjada and Fanfik - of young individuals coming to terms with their social bodies and the normative beauty ideals they are confronted with.

A very significant context should be brought in here: in one of his letters to $\mathrm{Mu}$ sierowicz, Raszewski, mentioned above in relation to the ideological background of the cycle (the theory of islands), depicts an imaginary academic conference devoted to the author's fiction. ${ }^{113}$ Written under the disguise of one "Jan Lewandowski", the letter is a playful extrapolation of Raszewski's analysis of Jeżycjada. Other than following the humorous convention of his correspondence with Musierowicz, Raszewski, himself a renowned scholar, seems to try and justify here his deep admiration of what the Academia might have considered a trivial matter - that is, literature for adolescent girls. Raszewski hides behind a ludic strategy, and one cannot be absolutely sure if he agrees with his imaginary academics or mocks them softly.

A fictional scholar, Mariola Sandałek [Mariola Little Sandal Shoe] from a provincial teachers college, is introduced in a fragment of the said letter, along with her contribution on "the problems of make-up used by the characters from Jeżycjada, specifically by Cesia and Ida". ${ }^{114}$ Raszewski situates make-up in the ranks of the elements that build up the verisimilitude of Jeżycjada. He observes that the mascara Cesia uses is period-specific, and some narrative situations related to this object would not be possible ten years later, with different mascaras on the market. ${ }^{115} \mathrm{He}$ admires this small detail for its perfect incorporation into the fabric of the story. Cesia uses so-called cake mascara (sold in a small box) that requires adding some liquid to form a paste to be applied on the lashes; in 1989, as Raszewski notices, a typical mascara would be a cream one, packed in an oblong container with a long thin oval brush hidden inside. Spitting into a mascara (a character protests against this being done to her property by her younger sister) can be done only with the vintage cake variety.

Characteristically, Raszewski says that listening to Mariola Little Sandal Shoe, M.A., "the male part of the auditorium learned by the way - with great interest -

\footnotetext{
113 Z. Raszewski, Listy do Małgorzaty Musierowicz, Kraków 1994, pp. 20-33.

114 Ibid., p. 33.

115 Ibid.
} 
how to do eyes. (That is, how to blacken the lashes and brows, how to put eye shadow on the lids and under the eye.)" ${ }^{116}$ Make-up is thus presented as a specifically feminine, hermetic occupation, out of the range of male culture. Pointing at the presence of make-up in Szóstka klepka and Kwiat kalafiora, Raszewski stops at highlighting its verisimilitude-related function.

I argue that make-up can also be analysed as related to the construction of the social body, and as follows, to the ideological framework of Musierowicz's fiction. Szósta klepka [The Sixth Wit] is the point of departure here but as cosmetics appear in other Musierowicz texts, examples from a selection of Musierowicz's texts are also accounted for.

Published in 1977, Szósta klepka is the first Jeżycjada novel. It does not feature the Borejkos yet, as it is concerned with another intelligentsia family, the Żaks. Its plot starts on the $10^{\text {th }}$ of December, 1975, against the backdrop of a bleak snowy winter, shortages of goods (cotton wool, used for sanitary protection during menstruation, is a real treat worth hunting for when it is supplied to a local shop), and communism. The Żaks' household consists of grandfather, artistic mother (a sculptor), father who works as an engineer, three children (Julia, who is an art student; 16-year-old Celestyna, or Cesia; and the Żaks' mischievous nephew, six-year-old Bobcio); as well as Bobcio's divorced mother Wiesia, later on joined by another single mother and her new-born baby. Among the polyphony of voices, with sections written from the perspectives of several characters, Celestyna remains the leading one. She has started her secondary school recently and still does not feel comfortable in the new environment. Although she represents the standardised Western beauty ideal (intensely green eyes; voluptuous blond hair; regular features; healthy light-coloured skin etc.), she suffers from a considerable lack of self-assurance and considers herself physically unattractive. Her elder sister is the beautiful and glamorous one: "a fine student of the Fine Arts endowed by lavish nature not only with numerous talents, but also with a beauty worthy of a Spanish film star".117

The Żaks household is an open one, as the family readily invites guests and reaches out to help other people; however, the slightly shy and composed Celestyna ${ }^{118}$ yields to other people's demands too often, engaging in endless household chores or tutoring a school friend. Nevertheless, at the end of the novel, she is able to overcome the invisibility that she has been suffering from and finds her individual voice. The novel presents the process of re-discovering one's self, and growing up to be the person one feels comfortable being in the contexts of sexuality and the creation of the gendered social body.

116 Ibid.

117 M. Musierowicz, Szósta klepka, Warszawa 2002, p. 8: "piękna studentka sztuk pięknych obdarzona przez rozrzutną Naturę nie tylko licznymi talentami, lecz i urodą hiszpańskiej gwiazdy filmowej”.

118 Or Cesia, or Cielęcina, as she is called by her family; the second name is the diminutive form of Celestyna, while the thirds one means "Veal" in Polish. 
An important storyworld existent that exemplifies this transition is make-up. There are three notable fragments in Szósta klepka concerned with Celestyna's experiments with the transformative power of cosmetics. As stated in the text, she is "objectively" attractive. Looking at the mirror, though:

She finds her face an unintelligent piece of pink meat. Can the sight of an object like this make the heart of some glorious boy go ablaze with love? Out of the question. ${ }^{19}$

The fragment of the novel concerned with the exposition of her character depicts Celestyna in the middle of her morning routine. She wakes up and gets up, unwillingly; goes to the cold and gloomy bathroom and scrutinises her face and her - "much too fat" - calves. She tries to make herself some tea (there is no running water in the tap); and hurries to school, ignoring her father's note asking her to fix the water problem. The third-person narration gives readers a glimpse of her thoughts: she is going to take an important mathematics test, but to her mind this is not as important as her looks. Before she leaves, she can see that "on the mirror shelf [in the corridor] there was some new interesting little box with golden lettering $<<$ Elizabeth Arden $>>"{ }^{120}$ It is her sister's luxurious mascara and she decides to use it. Her eyes are slightly more accentuated and appear to be greener, and she likes this, but still, she is not satisfied with the overall impression: her alluring poses in front of the mirror are ridiculous and she knows it. When she gets out and walks down the street, she can see her reflection in a hand mirror on the display of a kiosk, and it is still "a sore sight". ${ }^{121}$

The second notable scene involving cosmetics takes place before Christmas, when Julia, the elder sister who earns some extra money as an interior decorator, gives Celestyna Max Factor mascara and green eye-liner, both bought in a Moda Polska boutique. ${ }^{122}$ Celestyna's mother opposes, because of the price (far too expensive for a teenager), and the family starts to quarrel. The grandfather declares, finally, that Celestyna should take the gift. She hides in the bathroom and applies the cosmetics, but again, is so dissatisfied with the outcome that she wants to cry, only to

119 M. Musierowicz, op. cit., p. 9: "Ona sama uważa swoją twarz za nieinteligentny kawałek różowego mięsa. Czy widok takiego obiektu może sprawić, że serce jakiegoś wspaniałego chłopaka zabije nagle płomiennym uczuciem? Wykluczone."

120 M. Musierowicz, op. cit., pp. 9-10: "na półce pod lustrem leżało jakieś nowe interesujące pudełeczko ze złotym napisem "Elizabeth Arden".

${ }^{121}$ M. Musierowicz, op. cit., p. 10: "rozdzierający widok".

122 Moda Polska was a fashion company and a chain of boutiques, founded in the People's Republic of Poland in 1958 to develop and promote a national fashion industry. The paradoxical idea was to support communist haute couture and pret-a-porter, designed and produced locally, a kind of a countermeasure against Western fashion. The designers tried to do their best, given the circumstances (the shortages of fabrics and other resources), and as a result, some of the designs were notable stateof-the-art creations. Moda Polska boutiques were synonymous with luxury and style. (See also J. Antkowiak in A. Pelka, Teksas-land. Moda młodzieżowa w PRL, Warszawa 2007, pp. 105-111; A. Pelka, Z [politycznym] fasonem. Moda młodzieżowa w PRL i NRD, Gdańsk 2013, pp. 72-78). 
remind herself that it would destroy her make-up. She leaves the bathroom and no one pays any attention to her new image. Then again, when she does some shopping, dressed in her sister's old (but still fabulous) overcoat, not only does she contemplate and enjoy her reflection in a shop window, but she also impresses her secret admirer Hajduk, and later on makes an unexpected acquaintance with a "bearded guy" that asks her out for a date. Another fragment presents, actually, the lack of make-up. With no make-up on, dressed in her own baggy overcoat, Celestyna goes on a date with the bearded university student; he fails to recognise her but nonetheless tries to pick her up.

The rhetoric of make-up in Szósta klepka is definitely one of "deception and disguise". A sign of vanity, make-up is unnecessary and cumbersome: with her make-up on, Celestyna has to be careful not to cry, and there are depictions of the mascara smeared round her eyes. A similar technique is used in Kwiat kalafiora [The Cauliflower], when one of the Borejko sisters, Ida, applies too much make-up on her eyelids, and as a result suffers from a disfiguring allergy, with swollen lids and tears coming out of her eyes. ${ }^{123}$ Her desire to look glamorous and to pose as older is apparently punished.

Female attractiveness is evaluated by the male gaze that can see through the mascara and eye-liner: Celestyna's true love admires her no matter what she is wearing, or not wearing, on her face (but notices some positive difference, when she is made-up; this, however, could be ascribed more to Celestyna's increased self-assurance than to her features). Celestyna's growing up and gaining recognition consists, in part, in getting fashionable clothes and some make-up items of her own: the means and the right to create her own social body and become visible - but all within the prescribed patriarchal limits (her sister gives her the cosmetics, but it is the grandfather that sanctions her use of the mascara and eye-liner). Celestyna would use make-up on and off, and finally she would be satisfied with her looks.

By depicting the acts of applying make-up, Szósta klepka presents the process of writing Celestyna's face into the social fabric, negotiating her identity and position in society. It is not a coincidence that the cosmetics she uses come from Elizabeth Arden and Max Factor brands. Both were considered high-end, difficult to get, and simply expensive at that time, bringing forth the connotations of the behind-the-iron-curtain allure. A real brand introduced into a fictional world

may seem logical, if it is perceived as an aid to description and to the development of a mental image to support the story. [...] brands have an evocative power, which the author may make use of to fuel the reader's imagination. Placement can thus allow authors a certain economy, even as it enriches the scene, or renders it more precise in the reader's mind, if he or she knows the brand. ${ }^{124}$

${ }^{123}$ M. Musierowicz, Kwiat kalafiora, Kraków 1992, pp. 15, 66-67.

124 J.-M. Lehu, Branded Entertainment: Product Placement and Brand Strategy in the Entertainment Business, London and Philadelphia 2007, p. 166. 
The little box with the golden "Elizabeth Arden" letters seems to be reminiscent of Alice's bottles of magic concoctions in Wonderland. Yet does it have the power to transform Celestyna? Contrary to the notion of glamour, Szósta klepka appears to postulate some essentialist inner beauty that just waits to be revealed when a young woman embraces her femininity. Make-up, when used in moderation, is a proper adult thing to rely on. Nevertheless, the novel also suggests that one should not get too attached to it, or dependent on it.

Exactly the same pattern is to be found in Kwiat kalafiora: dressing herself up to look like "an elegant woman" for a family gathering, Gabriela tries to adorn her eyes with the "green slime" that she has taken from her sister Ida's purse. ${ }^{125}$ She applies the eye shadow on her lids (literally, she "painted her lids green with the slime") but decides that she resembles a lizard and finally removes her make-up. ${ }^{126}$ Glamour is out of question, and she does not need make-up to look attractive: the scene takes place at the very end of the novel, which closes with Gabriela in the arms of a boy who wants to date her. On the other hand, her mother, who has just returned from hospital, takes a bath and then meets and greets her guests "freshly made-up". ${ }^{127}$ For Gabriela's mother, make-up is a normalised everyday routine that befits an adult female.

Introducing cosmetics into her other texts, the author persistently utilises the rhetoric of "make-up as disguise and deception". An excellent example of this technique is the depiction of Aniela's transformation into a house-maid. ${ }^{128}$ The girl wants to get a job at the house of the boy she has a crush on. An intelligent, resourceful, and quick-witted high school student, she wants to change her appearance and fit in with the stereotype of the house-maid. The make-up look she creates could be read as a lower-class one: the foundation a few shades brighter than her skin and an orange lipstick that matched the complexion of a light-skinned woman, as the narrator explains, would strike a viewer as "jarring". Pulled up high and teased, her hair is covered with a thick layer of hair-spray - a beehive hair-do that "gives her face a languid look"."129

Aniela is a working-class girl with aspirations and ambition; interested in literature and arts, she has the potential of becoming an acceptable Borejko-like persona. The make-up style she uses as a disguise signifies a lack of taste and characterises an individual falling into the category of the menacing other - Aniela furthers herself away from the Borejko ideal. The underprivileged are diametrically different from the Jeżycjada's intelligentsia, and in the storyworld it literally shows.

125 M. Musierowicz, Kwiat kalafiora, p. 178.

126 Ibid.: "pomalowała mazidłem powieki na kolor zielony”; "uznała, że wygląda jak jaszczurka, starła farbę z oczu”.

127 Ibid.: "świeżo umalowana mama".

128 M. Musierowicz, Kłamczucha, Warszawa 1991, p. 71.

129 Ibid., p. 71: "nadała jej twarzy wyraz ociężałości”. 
The "Make-up as disguise" trope is also present in the depictions of women who happen to look different from what a given (male) character remembers from the past. In Córka Robrojka [Robrojek's Daughter], the eponymous character comes across a woman who used to be his high school love: "Aniela had not changed at all! but for her make-up. Back then she did not paint her eyelids brown, and her lips - red. Other than that, everything was as always [...]". ${ }^{130}$ This is a very sketchy description. A manly man as he is, Robrojek can only perceive make-up as smudges of colour on the face. The description is laconic. It is also followed by a series of exclamatory epithets: Robrojek admires Aniela's "Spanish eyes", "brilliant teeth" and "brows like little velvet ribbons"131, all being the "natural" (innate) qualities of the body. Józef Pałys (Ida Borejko's son), a character from McDusia, has a similar experience, welcoming an old romantic crush at the train station,

He couldn't see any other passengers, or anything apart from this charming, funny face of hers, laughing out at his direction so broadly, sincerely, and nicely as always, yet looking somehow different. It was only when he approached her closely he was able to see that she had make-up round her eyes and on her lips — and that made her look different. ${ }^{132}$

However, the ultimate "make-up as disguise" trope implementation can be found in the same novel, in relation to Laura Pyziak (Gabriela Borejko's daughter). Laura is getting married. She has decided to invite an old school friend to the wedding ceremony, an unrefined working-class person, a prosthetic dentistry technician with sisters in the beauty business (a hairdresser, make-up artist, personal trainer etc.). As a wedding gift, they give Laura a hairdo and create her bridal make-up look. They do their best but since the class distinctions are irreconcilable, the result is in the Borejkos' eyes - catastrophic. Laura looks like a "very mature primadonna playing the part of Madame Pompadour". ${ }^{133}$ Due to some complications with the wedding (Laura loses her wedding dress), the bride cries, which ruins her make-up. In a scene ripe with symbolic violence, her husband-to-be takes Laura to the bathroom, forcibly removes the cosmetics from her face, rubbing it first with soap and hot water, and then with cold ${ }^{134}$, and combs her hair to get rid of the elaborate up-do. ${ }^{135}$ "He wiped her face dry with care, patting it like a child's face". ${ }^{136}$ Now, Laura

${ }^{130}$ M. Musierowicz, Córka Robrojka, Łódź 1996, p. 168: “Aniela wcale się nie zmieniła! — jeśli nie liczyć makijażu. Kiedyś nie malowała powiek na brązowo, a ust - na czerwono”.

131 Ibid., p. 168.

132 M. Musierowicz, McDusia, Łódź 2012, p. 121: "Nie widział innych podróżnych ani w ogóle niczego poza tą jej uroczą, zabawną twarzą, która śmiała się do niego tak szeroko, szczerze i miło jak zawsze, a która przecież wyglądała jakoś inaczej. Dopiero kiedy był całkiem blisko, dostrzegł, że miała umalowane oczy i usta - i że to właśnie ją tak zmieniało".

133 Ibid., p. 199: "bardzo dojrzała primadonna obsadzona w roli Madame Pompadour".

134 It could be noted that this scene evades: bridal make-up cannot be easily removed with neither cold, nor hot water and soap.

135 Ibid., p. 219.

136 Ibid., "Wytarł ją w końcu troskliwie ręcznikiem, poklepując jak małe dziecko". 
looks "natural" and "clean", and can take part in the wedding ceremony, dressed in the fifty-one-year-old skirt and jacket her grandmother wore at her wedding.

Removing the make-up might be suggestive of a christening (metaphorically, water washes away Laura's sins and marks the start of her new life), but it could also be read as an act of violence, an intrusion into one's personal space. That sequence of events marks the incorporation of Laura into the framework of the family values. Laura's father, Janusz Pyziak, abandoned his wife and baby children, and then he divorced his wife, Gabriela. In the previous instalments of the cycle, Laura is presented as tainted with her father's un-Borejkovian characteristics: pride, conceit, aloofness, and cruelty. In Tygrys $i$ Róża [The Tiger and the Rose], 14-year-old Laura runs away from home to visit her aunt and find something about her absent father (her family keeps him a secret from her, and she feels an acute sense of not belonging). This is presented as a selfish and stupid decision.

\section{Body as a performance — Fanfik by Osińska}

The first chapter of Fanfik starts with the depiction of the main character regurgitating in a school toilet. Presented as female, Tosia is dressed up in a bombastic white cocktail dress and wears multi-layered, professionally blended make-up. Tosia hates make-up, but is forced to wear it. Tosia's aunt is a make-up artist; she uses cosmetics to make Tosia the person she - as well as society - would accept. As a result, Tosia hates make-up; the character "hated the process of applying mascara on her own pale lashes". 137

In Osińska's storyworld, cosmetics are part and parcel of teenage life. School bathrooms are used first and foremost for applying lip gloss and removing smudges of mascara. Tosia's girlfriends, who are just learning how to do make-up, and are impressed by Tosia's professional looks and full face of expensive products ("The elderly make such a drama whenever I do a stronger eye!", complains one of them ${ }^{138}$ ). What impresses them even more are the free samples of make-up products from Tosia's aunt. Thanks to cosmetics - both the make-up on the face and the samples Tosia gives away (the Dior brand is mentioned) - the character performs social mimicry. The social body Tosia is forced to construct fails to reflect his internalised gender identity. A breakthrough is signalised by the act of removing make-up. Staying at a friend's place and changing wet clothes after heavy rain, the main character also takes the foundation and mascara off his face. It is the moment when, for the very first time in his life, Tosia/Tosiek enjoys his reflection in a mirror. ${ }^{139}$

137 N. Osińska, Fanfik, Warszawa 2016, p. 11.

138 Ibid., p. 38: "Moi starzy robią raban, jak tylko bardziej zrobię oko!".

139 Ibid., p. 91. 
Mirrors are important elements both in Osińska's and in Musierowicz's storyworlds. Taking into account Tosia's unusual appearance - long golden curls parted in the middle, blue eyes, white dress supported with a frothy petticoat ${ }^{140}$, all bringing forth the association with the conventional depiction of Lewis Carroll's heroine - in Fanfik they could be probably suggestive of Alice in Wonderland, making the novel a "brilliantly written, intelligent, and a very funny history at times, about Alice that finally takes a look at the looking glass in the Wonderland and can see someone she has not expected to see" ${ }^{141}$ Fanfik plays with traditional fairy-tale elements, such the opposition between as the good (early childhood) mother and the bad (adolescence period) mother. ${ }^{142}$ It should be noted that Musierowicz's fiction is also discussed in terms of fairy tales as it abounds with fairytale morphemes and narratives specifically modelled on a recognisable story: for example, Szóstka klepka is reminiscent of Rapunzel, while Córka Robrojka follows The Beauty and the Beast. ${ }^{143}$

Mirrors mark the stages of the main character's transition from negation to acceptance of his body. Both Tosia/Tosiek and Celestyna can enjoy their reflections only when they accept and internalise their image, and in both cases it is a gradual process. Celestyna's most important mirror is her boyfriend-to-be, Hajduk. Fanfik, however, presents a much more violent transformation and leaves it for the main character to find out who he is on his own.

At some point he decides to get rid of nail polish and to stop doing make-up: "She didn't make up her face, she did not intend to do it, never again. What an incredible relief! And this was just the beginning". ${ }^{144}$ Paradoxically, soon enough, he decides to use bronzer and highlighter to contour his face to make it look more masculine. ${ }^{145}$ The effect of high quality cosmetics, supported with the know-how he has previously acquired from his aunt and the Internet tutorials for transgender people results in the beautiful face of a "pure-blood prince", nearly making elated Tosia/Tosiek cry with emotion. ${ }^{146}$ This scene seems to be the mirror (nomen omen) reflection of Celestyna's applying the mascara and green eye-liner.

Depending on the specific context, make-up can be as empowering as it could be disempowering. As has been shown, compared with Musierowicz, Osińska’s novel

${ }^{140}$ N. Osińska, op. cit., p. 10.

141 A. Szymańska, “Fanfik, Natalia Osińska. Recenzja," [in:] Gryzipiór Blog, January 2017, http:// www.gryzipior.pl/2017/01/fanfik-natalia-osinska-recenzja.html (access: 30.06.2017): "świetnie napisana, inteligentna i chwilami bardzo zabawna historia o tym, jak Alicja w Krainie Czarów wreszcie spojrzała w to swoje lustro i zobaczyła w nim kogoś, kogo się nie spodziewała”.

142 Ibid.

143 I. Szpara, "Baśniowe morfemy w twórczości Małgorzaty Musierowicz," [in:] Między Bombolandia i Jeżycjadą. Małgorzaty Musierowicz makro- i mikrokosmos, ed. K. Heska-Kwaśniewicz and A. Gomóła, Katowice 2003, pp. 70-71.

${ }^{144}$ N. Osińska, op. cit., p. 110: "Nie umalowała twarzy, nie zamierzała tego robić nigdy więcej. Co za nieprawdopodobna ulga! A to był dopiero początek."

145 Ibid., pp. 133-134.

146 Ibid., p. 134: "rasowy książęe. 
is much more thorough in her analysis of the social functions of make-up. Musierowicz's storyworld appears to be related to traditional conservative values: it depicts a stable value system. This is specifically made explicit in Kłamczucha [The Liar]: the character of Aniela believes in postmodern relativity, yet in the process of self-realisation she turns to the values shared by the Borejkos. Osińska's text is concerned with a reverse process. When Tosiek chooses a birthday gift for his gay friend Leon, who would like to experiment with his feminine side, he decides to give him a collection of nail polishes, along with the necessary utensils. This is perhaps the most significant scene of the novel when it comes to cosmetics as narrative devices. "I am so happy I don't have to use this anymore!", says Tosiek. "Do I have to?" asks Leon in reply, and the answer Tosiek offers is: "Only if you want to". ${ }^{147}$ Make-up could be liberating when it is a free choice that supports one's internalised gender and body image; otherwise, if imposed on an individual by the social norms and related to gender policing, it is limiting and destructive.

The differences between Fanfik and the stories by Musierowicz can also be explained in the light of Nikolajeva's concept of aetonormativity. ${ }^{148}$ Make-up is presented as positive when not enforced by grown-ups. Peer-to-peer exchange of cosmetic know-how could be positive if it brings joy to the people involved, and it could serve the subversive creation of non-normative social body. In the era of YouTube, make-up gurus, and a thriving cosmetics industry, the characters' use of make-up could be read as contributing to characterisation and verisimilitude. At the same time, it could be read as a reference to Musierowiczs use of the motif of make-up in her texts, specifically in Szósta klepka.

While in Musierowicz's Jeżycjada make-up is another social skill that has to be internalised along the way of growing up into an acceptable member of society, Osińska’s debut shows that make-up - being a social practice - is complicated and multifunctional. It can be used consciously for the creation of an un/acceptable social body. In Fanfik, the make-up routines are the means of introducing a heterological approach, arguing that "firstly, that norms are arbitrary, and secondly, and perhaps more importantly, that the whole argument about $<<$ norms $>>$ and $<<$ deviations $\rangle>$ " gives the norm priority over deviation, and thus more authority and power". ${ }^{149}$

\section{Bibliography}

anuszka_ha3.agh.edu.pl. 2016. "Natalia Osińska, "Fanfik” — ktoś czytał?” ESD Forum, December11. http://forum.gazeta.pl/forum/w,25788,162814260,162814260,Natalia_Osinska_Fanfik_ktos_czytal_html.

Biedrzycki, Krzysztof. 1999. Małgorzata Musierowicz i Borejkowie. Kraków: Universitas.

147 Ibid., p. 253.

148 M. Nikolajeva, op. cit.

149 Ibid., p. 16. 
Biedrzycki, Krzysztof. 2014. “Dom, kobiety, kultura. O powieściach Małgorzaty Musierowicz.” Nowa Dekada Krakowska nr 1/2 (11/12) 2014: 22-27.

Butler, Judith. 1990. Gender Trouble. Feminism and The Subversion of Identity. New York and London: Routledge.

Craik, Jennifer. 2005. The Face of Fashion: Cultural Studies in Fashion. London: Routledge.

Dawidowicz-Chymkowska, Olga. 2012. "<<Wynaturzone >> Forum Fanów Małgorzaty Musierowicz jako interakcyjna maszyna interpretacyjna: studium przypadku.” Teksty Drugie 6: 287-299.

Dunin, Kinga. 2016. “Osobiście uważam, że...” Krytyka Polityczna, 30 December, http://krytykapolityczna.pl/kultura/czytaj-dalej/kinga-dunin-czyta/osobiscie-uwazam-ze.

DzikazRadzikiem. 2014. "Ratunku, jestem Romą! czyli o powieściach Małgorzaty Musierowicz słów kilka." Kacza Zupa, August 27. https://kaczazupa.wordpress.com/2014/08/26/ratunku-jestemroma-czyli-o-powiesciach-malgorzaty-musierowicz-slow-kilka.

Eldridge, Lisa. 2015. Facepaint. The History of Make Up. New York: Abrams.

Genette, Gerard. 1992. "Palimpsesty. Literatura drugiego stopnia." In Wspótczesna teoria badań literackich za granica, edited by Henryk Markiewicz, pp. 317-366. Kraków: Wydawnictwo Literackie.

Genette, Gerard. 2001. Paratexts: Thresholds of Interpretation. Lincoln and London: Cambridge University Press.

Goffman, Ervin. 1956. The Presentation of Self in Everyday Life. Edinburgh: University of Edinburgh Press.

Golkar, Saeid. 2011. "Politics of Piety: The Basij and Moral Control of Iranian Society." Journal of the Middle East and Africa 2: 207-219.

Gundle, Stephen. 2008. Glamour: A History. Oxford: Oxford University Press.

Jauss, Hans Robert. 1999. Historia literatury jako prowokacja. Warszawa: Wydawnictwo Instytutu Badań Literackich.

Jenkins, Henry. 2006. Convergence Culture: Where Old and New Media Collide. New York: New York University Press.

Kobus, Aldona. 2017. "Najbardziej potrzebna książka 2016 roku. Queerowe dzieci i Fanfik — recenzja niewolna od spoilerów." Szuflada Net, January 22. http://szuflada.net/najbardziej-potrzebna-ksiazka-2016-roku-queerowe-dzieci-i-fanfik-recenzja-niewolna-od-spoilerow.

Kobus, Aldona. 2017. "Przenieść fanfiction do mainstreamu - wolny od spoilerów wywiad z Natalią Osińską.” Szuflada Net, January 29, http://szuflada.net/przeniesc-fanfiction-do-mainstreamuwolny-od-spoilerow-wywiad-z-natalia-osinska.

Krytyka Polityczna, 2017. "About Us., http://krytykapolityczna.pl/o-nas/eng.

Lehu, Jean-Marc. 2007. Branded Entertainment: Product Placement and Brand Strategy in the Entertainment Business. London and Philadelphia: Kogan Page.

Maczunder, Halina. 2000. Humor i komizm sytuacyjny w wybranych powieściach Małgorzaty Musierowicz. Warszawa: Dom Wydawniczy Elipsa.

Mahdavi, Pardis. 2009. "Who will catch me if I fall? Health and the infrastructure of risk for urban youth iraniansa." In Contemporary Iran. Economy, Society, Politics, edited by Ali Gheissari, pp. 150-193. Oxford: Oxford University Press.

Marudzińska, Ola [Rusty Angel]. 2016. "Manic pixie dream human — Fanfik Natalii Osińskiej." Meanwhile On Vulcan Blog, December 5, http://meanwhile-on-vulcan.blogspot.com/2016/12/manic-pixie-dream-human-fanfik-natalii.html? $\mathrm{m}=1$.

Miller, Piotr. 2017. “Szukając własnego głosu. O Fanfiku Natalii Osińskiej." Kultura Liberalna, January 24, http://kulturaliberalna.pl/2017/01/24/piotr-miller-o-fanfiku-natalii-osinskiej-kl-dzieciom/.

Musierowicz, Małgorzata. 1991. Kłamczucha. Warszawa: Nasza Księgarnia.

Musierowicz, Małgorzata. 1992. Kwiat kalafiora. Kraków: Signum.

Musierowicz, Małgorzata. 1996. Córka Robrojka. Łódź: Akapit Press.

Musierowicz, Małgorzata. 2002. Szósta klepka. Łódź: Akapit Press.

Musierowicz, Małgorzata. 2012. McDusia. Łódź: Akapit Press.

Miscellanea Posttotalitariana Wratislaviensia 7, 2017

(C) for this edition by CNS 
Nessa. 2016. "Najbardziej zaskakująca młodzieżówka." YouTube.com, December 8, https://www.youtube. com/watch?v=2iIbWIbM1xA.

Nikolaieva, Maria. 2009. “Theory, post-theory and aetonormative theory."Neohelicon XXXIV 1: 13-24. doi: 10.1007/s11059-009-1002-4.

noida. 2017. "Musierowicz w wersji LGBTQ, czyli Fanfik Natalii Osińskiej."Kacza Zupa Blog, January 11, https://kaczazupa.wordpress.com/2017/01/11/musierowicz-w-wersji-lgbtq-czyli-fanfiknatalii-osinskiej/.

Osińska, Natalia. 2016. Fanfik. Warszawa: Wydawnictwo Krytyki Politycznej.

Pelka, Anna. 2007. Teksas-land. Moda młodzieżowa w PRL. Warszawa: Wydawnictwo Trio.

Pelka, Anna. 2013. Z [politycznym] fasonem. Moda młodzieżowa w PRL i NRD. Gdańsk: słowo/obraz terytoria.

Piątek, Tomasz. 2013. “McDuszno." Krytyka Polityczna, January 18, http://krytykapolityczna.pl/archiwum/felietony-archiwalne/tomasz-piatek/mcduszno/2013/.

Potworia. 2016. "Natalia Osińska, 'Fanfik' - ktoś czytał?” ESD Forum, December 29, http://forum. gazeta.pl/forum/w,25788,162814260,162814260,Natalia_Osinska_Fanfik_ktos_czytal_.html.

Prince, Gerald. 1997. "Foreword.” In Palimpsests. Literature in the Second Degree, by Gerard Genette, ix-xi. Lincoln and London: University of Nebraska Press.

Raszewski, Zbigniew. 1994. Listy do Małgorzaty Musierowicz. Kraków: Wydawnictwo Znak.

Ryan, Marie-Laure. 2014. "Story/Worlds/Media. Tuning the instruments of a media-conscious narratology." In Storyworlds Across Media. Toward a Media-Conscious Narratology, edited by Marie-Laure Ryan and Jan-Noel Thon, 25-49. Lincoln and London: University of Nebraska Press.

Schechner, Richard. 1977. Performance Theory. New York and London: Routledge.

Stankiewicz, Bogumiła. 2010. "Model kobiecości w Jeżycjadzie." In Świat literacki Małgorzaty Musierowicz, edited by Andrzej Sulikowski and Marlena Niezgoda, 111-128. Szczecin: Volumina.pl.

Szczerba, Dorota. 2004. "Wstęp." In Poznań Borejków. Spacer z bohaterami powieści Małgorzaty Musierowicz, edited by Kinga Czachowska and Dorota Szczerba, pp. 9-10. Poznań: Media Rodzina.

Szpara, Ireneusz. 2003. "Baśniowe morfemy w twórczości Małgorzaty Musierowicz." In Między Bombolandia i Jeżycjada. Małgorzaty Musierowicz makro- i mikrokosmos, edited by Krystyna Heska-Kwaśniewicz and Anna Gomóła, pp. 70-71. Katowice: Wydawnictwo Uniwersystetu Śląskiego.

Szybowicz, Eliza. 2013. "Była fanka czyta Musierowicz." Krytyka Polityczna, February 11, http://krytykapolityczna.pl/kultura/czytaj-dalej/byla-fanka-czyta-musierowicz.

Szymańska, Alicja. 2017. “Fanfik, Natalia Osińska. Recenzja.” Gryzipiór Blog, January, http://www.gryzipior.pl/2017/01/fanfik-natalia-osinska-recenzja.html.

Wilson, Elizabeth. 2003. Adorned in Dreams. Fashion and Modernity. London and New York: I. B. Tauris. Wolf, Naomi. 2002. The Beauty Myth. How Images of Beauty Are Used Against Women. New York: Harper Collins.

Accepted for publication: 9.09.2017

Miscellanea Posttotalitariana Wratislaviensia 7, 2017

(C) for this edition by CNS 